\section{4) Papel dos flavonoides na doença de Parkinson}

\author{
Jackson da Silva Pereira'; Fabiani Lage Rodrigues Beal²
}

\section{Resumo}

A Doença de Parkinson (DP) é uma doença neurodegenerativa, crônica e progressiva, que acomete em geral pessoas idosas pela produção de neuroinflamação e ela ocorre pela perda de neurônios do sistema nervoso central. A estimativa em 2005, do número de indivíduos com idade acima de 50 anos apresentando a doença de Parkinson foi de 4,1, espera-se que esse número dobre entre 8,7 e 9,3 milhões em 2030. O uso de flavonoides na dieta com indivíduos com DP, conseguem minimizar ou retardar a progressão da doença e seus sintomas. Esses compostos estudados têm incidência na melhora da função cognitiva e previnem distúrbios neurodegenerativos em humanos. Compostos naturais, como flavonoides, parecem possuir potencial neuroprotetor provavelmente relacionado à sua capacidade de modular as respostas inflamatórias envolvidas em doenças neurodegenerativas, inibindo a sinalização do Fator Transcrição Nuclear kB. A hipótese é que os flavonoides protegem contra a neurodegeneração que ocorre na enfermidade da DP, com base nos relatos da literatura sobre efeitos antioxidantes e anti-inflamatórios dos flavonoides e o envolvimento da resposta neuroinflamatória e estresse oxidativo da doença. Entre os estudos observados nesta revisão compreende-se que a subclasse de flavonoides, os polifenóis possuem efeitos protetores. Os últimos estudos apontam para a importância de se entender a biodisponibilidade dos flavonóides, colocando em questão a quantidade de fruta que precisaria ser consumida diariamente para fornecer efeitos benéficos contra o envelhecimento cerebral ou doenças neurodegenerativas, por quanto tempo uma dieta rica em frutos silvestres seria necessária para prevenção, tratamento ou manutenção das cognições cerebrais e motoras.

Palavras chaves: flavonoides, neurodegenerativas, polifenóis.

\section{Abstract}

Parkinson's disease (PD) is a chronic, progressive neurodegenerative disease that usually affects older people due to the production of neuroinflammation. It occurs due to the loss of neurons of the central nervous system. The estimate in 2005 of the number of individuals over 50 years old with Parkinson's disease was 4.1. It is expected that this number doubles between 8.7 and 9.3 million in 2030. The use of flavonoids in the diet of individuals with PD can minimize or delay the progression of the disease and its symptoms. These

1 Graduando em Nutrição, Universidade Católica de Brasília, Águas Claras, Distrito Federal, Brasil. Endereço para correspondência: QS 07 Lote 01 - EPCT - 71966-700 - Águas Claras - Taguatinga - DF. Email: jackson.silvapereira@ hotmail.com

2 Professora no Programa de Pós-Graduação Stricto Sensu em Gerontologia, Universidade Católica de Brasília. Email: fabiani@p.ucb.br 
compounds have an effect on the improvement of cognitive function and prevent neurodegenerative disorders in humans. Natural compounds, such as flavonoids, appear to possess neuroprotective potential likely related to their ability to modulate the inflammatory responses involved in neurodegenerative diseases by inhibiting Nuclear Transcription Factor kB signaling. The hypothesis is that flavonoids protect against neurodegeneration that occurs in PD, based on the literature reports on antioxidant and anti-inflammatory effects of flavonoids and the involvement of the neuroinflammatory response and oxidative stress of the disease. Among the studies observed in this review it is understood that the subclass of flavonoids, polyphenols, have protective effects. Recent studies point to the importance of understanding the bioavailability of flavonoids, calling into question the amount of fruit that would need to be consumed daily to provide beneficial effects against brain aging or neurodegenerative diseases and for how long a diet rich in wild fruits would be needed for prevention, treatment or maintenance of cerebral and motor cognitions.

Keywords: flavonoids, neurodegenerative, polyphenols. 